Where the Dragon

Meets the Angry River 



\section{Where the Dragon \\ Meets the Angry River}

Nature and Power in the People's Republic of China

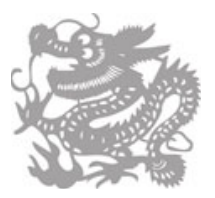

R. Edward Grumbine

OislandPress / Shearwater Books

Washington - Covelo $\cdot$ London 


\section{A Shearwater Book \\ Published by Island Press}

Copyright (C) 2010 R. Edward Grumbine

All rights reserved under International and Pan-American Copyright Conventions. No part of this book may be reproduced in any form or by any means without permission in writing from the publisher: Island Press,

I718 Connecticut Ave., NW, Suite 300, Washington, DC 20009.

Shearwater Books is a trademark of The Center for Resource Economics.

Library of Congress Cataloging-in-Publication Data

Grumbine, R. Edward.

Where the dragon meets the Angry River : nature and power in the People's

Republic of China / R. Edward Grumbine.

$$
\text { p.cm. }
$$

Includes bibliographical references and index. ISBN-I3: 978-I-59726-55I-5 (cloth : alk. paper) ISBN-IO: I-59726-55I-9 (cloth : alk. paper)

I. River engineering-China-Nujiang Lisuzu Zizhizhou.

2. Water resources development-Environmental aspects-ChinaYunnan Sheng. 3. Yunnan Sheng (China)-Economic conditions. 4. Yunnan Sheng (China)-Social conditions. I. Title. TC502.N85G89 2010 333.72095'35-dc22 2009045718

British Cataloguing-in-Publication data available.

Printed on recycled, acid-free paper 4

Design by David Bullen Design

Manufactured in the United States of America IO $\quad \begin{array}{lllllllll}9 & 8 & 7 & 6 & 5 & 4 & 3 & 2 & \text { I }\end{array}$ 


To the ancient Chinese masters

of philosophy, poetry, and painting;

and to the mountains, rivers, and

wildlands of the Middle Kingdom

that so inspired them. 



\section{Contents}

Introduction $\quad 3$

Chapter I The Highest Good II

Chapter 2 The Frontier and the Middle Kingdom 23

Chapter 3 Under the Jade Dragon 40

Chapter 4 Old Mountains, Young Parks 60

Chapter 5 In the Land of Twelve Thousand Rice Fields 83

Chapter 6 Into the Great Green Triangle 94

Chapter 7 The Dragon Meets the Angry River IO8

$\begin{array}{lll}\text { Chapter } 8 & \text { China } 2020 & \text { I23 }\end{array}$

Chapter 9 Conservation with Chinese Characteristics $\quad I 44$

Notes $\quad I 6 I$

Quotation references $\quad I 87$

Bibliography $\quad 193$

Acknowledgments 229

Index $23 I$ 
